\title{
Training Program for Kindergarten Teachers on Learning Through Project Approach
}

\author{
Dian Hartiningsih, Miranda Diponegoro, Evita Eddie Singgih \\ Faculty of Psychology, University of Indonesia, Depok, Indonesia \\ Corresponding e-mail: dian.hartiningsih@gmail.com
}

\begin{abstract}
In facing the 21st century, children need to be prepared in achieving the learning goals which include not only knowledge and skill, but also disposition and feeling in order to reach their optimum development level. Teachers, who are at the forerunner of education need to be equipped with the understanding and skill of implementing a learning method, such as the Project Approach, that enables children to face the challenges in the 21st century. Project Approach is an approach that utilizes active learning through a child centred learning method. Training and research was then established to get a deeper finding on whether there are significant influences from the training program that the kindergarten teachers received. Subject for this research are total of thirteen teachers from two different kindergarten schools. To explain this project approach training research, a quantitative research using pre and post study design was used, with a pre and post test instrument to analyze and quantify the result. The result of the research further suggested that through preliminary training program on learning with project approach, the teachers ability to explain project approach, including understanding, benefit and stages of project approach, have increased significantly; the teachers ability to design learning with project approach have also improved significantly. The result of learning design that the teachers had made shows a remarkable result for the first stage of the project approach; however the second and third design result was not as optimal. Challenges faced in the research will be elaborated further in the research discussion.
\end{abstract}

Keywords: project approach, teacher training, kindergarten, learning method, student centred

\section{INTRODUCTION}

Kindergarten in Indonesia as a form of Early Childhood Education focuses on the educational program for children age 4-7 years old. Each kindergarten schools vary on its learning method. There are schools that still use a teacher centred approach, but there are also schools that have already developed a child centred learning method.

In preparing children to face the 21 st century challenge, children need to be prepared in reaching their overall optimum development. According to Toffler (in Chiem \& Caswell, 2009), what's important in the 21 st century is not those who can't read or write, but more to those who isn't able to learn and continue to learn. Chiem \& Caswell (2009) also noted that we need to prepare children to be an active learner, those who have a positive attitude and confidence to be actively involved in the learning process. With the rise of technology, knowledge is access-able worldwide. What children need, is to be able to solve their own problems and find information, turn it into something innovative, creative and useful.

Changes in this world continue. Besides being an active learner, children must also be prepared to develop their social skills, such as to understand, respect and function well in a social context that encompass different perspective (Roopnarine \& Johnson 2009) and also the ability to collaborate, communicate, and to contribute to their society (Costa \& Kallick 2000).

As stated by National Association for the Education of Young Children (NAEYC, 1997) in the Developmentally Appropriate Practice that when today's children become adults, they will need the ability to 1) communicate well, respect others and 
engage with them to work through differences of opinion, and function well as member of the team; 2) analyze situations, make reasoned judgements and solve new problems as they emerge; 3 ) access information through various modes, including spoken and written language, and intelligently employ complex tools and technologies as they are developed; 4) continue to learn new approaches, skills, and knowledge as condition and needs change.

The above competencies that children need to develop in facing the 21 st century must be supported by a learning method that enable the learning goals to be achieved. Active learning is one method based on how the brain functions. Children who are actively involved in the learning process believed to be learning in their best way through activities that require children to think about the world around them, to use their skills while on investigation and exploration, to expresses questions about things around them, and to collaborate and interact with each other to gain knowledge (Moyles, Georgeson, Payler, 2011).

Characteristic on how children learn actively explains what Galbreath 1999 (in Kunandar 2007), had acknowledge that there has been a shift on today's educational practice, where as learning is not just based on fact but more based on project and problems, where as learning is not only through repetition and exercises but also through investigation and planning; and also a shift from competitive learning into more of collaborative learning.

\subsection{Project Approach}

An approach known as the "project approach" have lately developed in the educational program for kindergarten level, in schools throughout the world such as in the United States, Mexico, Canada, Singapore, Korea, Taiwan, New Zealand and Finland.

By definition, a project is an in depth study of a particular topic, usually undertaken by a whole class working on a subtopics in small groups, sometimes by a small group of children within a class, and occasionally by an individual child. The key feature of the project is that it is an investigation, a research that involves children seeking answers to questions they have formulated themselves, or in cooperation with their teacher and those that arise during the investigation (Katz \& Chard, 2000), about topics worth learning more about, something the children are interested in (Morrison, 2009; O'Donnell, Reeve \& Smith, 2012).

Project approach does not focus only on the result but also on the learning process (Gonzalez, 2011), that is on the active participation by children in each of the process of planning, developing and praising their own work. The learning process in project approach is like a story where it starts off in the beginning, middle and last at an end. Katz \& Chard, recommended learning through project approach to be implemented in three stages, beginning a project, developing a project and ends at concluding a project (in Lin, Moore \& Jang 2012). Beginning a project includes finding and agree upon a topic, then the teacher will gather all the information and knowledge that the children already know about the topic, make a topic web and finally list down all the questions they wanted to know about the topic. The next stage, developing a project is where the investigation takes place. Source of information could be from field work, guest visitors, or any media such as magazine, web, books, brochures, etc. All information gathered should be updated in the topic web. After investigation, it's time for the children to finish up and summarize all the information gathered from their learning experience in the concluding stage. Activities at this stage could be a form of drama, creative arts or product, presentation or explanation about the topic web.

There's several research result on how the project approach has impacted children. As been concluded by Devries, Reese-Learned \& Morgan 1991 (in Helm \& Katz 2001); that kindergarten children became more interactive, increase their interpersonal skills and negotiation skills. Another research that has been concluded by Edmiaston 1998 (in Lin, Moore \& Jang 2012), that social skills and collaboration skills of children has increased through team work activities which makes them able to work well with others.

Furthermore, Helm \& Katz (2001) describes that learning through project approach gives children the opportunity to be intellectually involved in the learning process. Children show initiative actions and also actively involved in problem solving. Through the project approach, children are prepared in reaching their optimum development level which encompassed all aspect of the learning goals. Katz \& Chard (2000) pointed out that learning through the project approach able to enrich four learning goals which include not only the acquisition and construction of knowledge, the mastery of basic and social skills, but also strengthen the social and 
intellectual dispositions as well as the development of desirable feeling.

Katz \& Chard (2000) stated that the project approach can be implemented starting even at the age of 3 years old, where children are able to show some initiative and responsibility. Schools implementing the project approach will benefit at preparing their children to master the competencies needed in facing the 21 st century. Implementation of the project approach itself lies heavily on the teachers. Teachers as facilitator needs to understand their role in delivering the learning process using the project approach. They need to have sufficient understanding on what is actually the project approach, why is it important and how is it delivered. Afterwards, teachers need to have the sufficient skills to be a facilitator in a learning process using the project approach.

This is actually where the problem lies in Indonesia. The ideal condition whereas teachers understand and have the skill to implement the project approach in kindergarten is limited. Lack of knowledge and skill should therefore be supported through a training program, in this case on the project approach learning method. Biech (2005) explains that through training, it helps participants to learn on new perspective and knowledge, learn new attitude and new skills which at the end could increase their performance. The training program that has been design by the researcher, consist of three level, where as for this research purpose will only covers level one and two. Further research should be done to cover the third level of the training program. After going through two levels of the training program; kindergarten teachers as forerunner of education is expected to be equipped with the sufficient knowledge on the project approach and knowledge of planning and designing the project approach lesson plan in their kindergarten.

\section{RESEARCH METHOD}

\subsection{Research Design}

The aim of the research is to get a finding on whether there are significant influence from the training program that the teachers develops, which is their ability to explain the meaning, benefit and stages of the project approach learning method and the ability to design a project approach lesson plan. To achieve this, the researcher had prepare a quantitative research with the before and after study design. Participants ability before and after the training, was then monitored to understand whether there are some or significant increases.

\subsection{Participants}

Participants in this research include all of the population of the kindergarten teacher in school with initial DM and school with initial KP which total up to 13 teachers. These teachers have never implement or attend a training program about the project approach.

\subsection{Procedure}

The first step of the research was to conduct need analysis using observation and interview to the participants, to gain insights on what the participant needed from the training. The result was a base for the researcher to design the training program.

Besides the training program itself, researcher also designs an instrument to analyze and quantify the result of the research. Before using the instrument, try out was conducted to a different group of teachers other than the participants, called the test subject. The result of the try out indicates items that are not suitable for the research, these items were then taken out and the revision of the instrument was done. Reliability and validity test are also conducted. The result of the reliability test shows 0.739; which means that the instrument is reliable to be used. The result of the validity test, with a coefficient score (r) near 0.6 also indicates that the instrument is valid to be use in this research.

The whole research process can be seen through the figure below. 


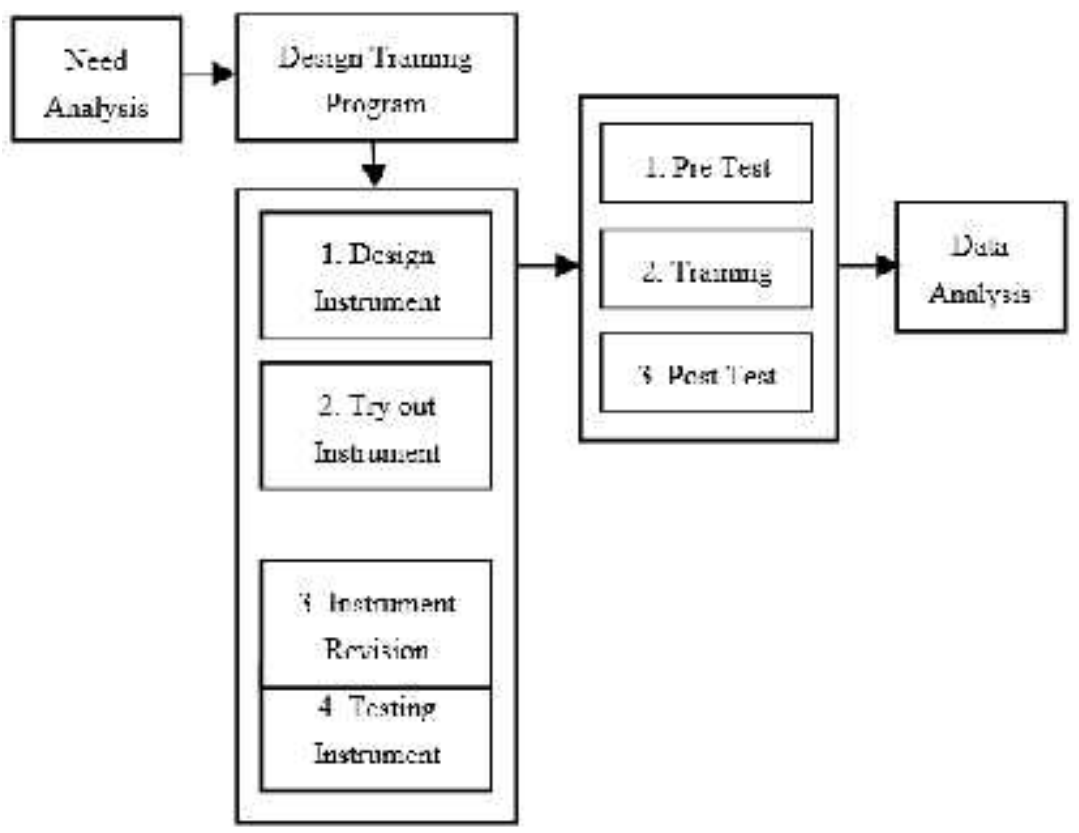

Figure 1. Research Process

\subsection{Training Program}

The design of the training program, as a form of learning, is based on the Lewin Change Theory and also Kolb Experiential Learning Cycle. Kurt Lewin (in Kritsonis 2005), believes that an individual goes through 3 steps as they were changing their behavior. First would be the Unfreezing process where old perspective starts to melt, then follow Movement process when a participant gain new understanding and last would be the Refreezing moment when new perspective is strengthen.

On this training program, the researcher starts off with a set of approach for changing mindset from conventional learning method to the active learning and project approach learning method. As for the experiential learning cycle, Kolb (in Laird 2003) defines learning new knowledge and understanding is develop and formed through experience. The cycle starts off with the concrete experience (CE), observations and reflections (OR), abstract concept (AC) and last active experimentation (AE).

Therefore in this training program, the researcher designs each sessions of the training program to follow the 4 stages of the cycle above.

The training program covers three levels. The first level aims in increasing the knowledge about the project approach, which includes the meaning, benefits and stages in implementing the project approach. The second level aims in increasing the knowledge of the teachers in planning and designing the project approach lesson plan. These two levels are the basic levels that need to be mastered firstly before taking the next level of training. The last training level then aims at increasing the skills of the teachers in implementing the project approach which includes on how to be a facilitator in the learning process. This research covers only the first and second level of training program for the beginning.

\subsection{Data Analysis}

First step in analyzing the data, researcher appoint scoring in the scale of 1-5. Score 1 indicates the answer to be very incomplete and score 5 indicates the answer to be very complete. After scoring is done, then analyzing data starts. For each items, the scoring is put into a data sheet. Analyzing data further on using paired sample t-test to show whether there are differences before and after the training program. 


\section{RESULT AND DISCUSSION}

\subsection{Need Analysis Result}

Both schools found to be 1) Open to new learning method 2) Kindergarten Teacher has the free will to use the learning method that they feel most suitable for learning 3) Need for training on learning method

Differences from both schools are as follow. 1) The learning method implemented in DM is more to thematic and drilling, where as in KP is more to thematic and multiple intelligences. 2) Kindergarten teachers in DM never received a training, where as teachers in KP received in house training regularly 3) Kindergarten teachers in DM doesn't have the responsibility to make lesson plan, where as teachers in KP design lesson plan regularly. 4) Timing available for training at DM is only after school hours where as in KP is at the school holiday.

The result of the need analysis above supports an adjustment on the training program for each school, such as which material needs attention, training schedule and how the training should be presented.

\subsection{Training Program Implementation}

Total participant that planned to join the training program is 13 teachers, but 2 teachers had other appointment, therefore total participant are 11 teachers. From timing issues, firstly the plan was for 6 hours training, but due to several obstacles, training could only be conducted for only 5 hours each day. Although there are some issues regarding the implementation, the participants show enthusiasm and actively participate in the training.

\subsection{Research Result}

The result using paired sample t-test for this research can be seen in the table below.

Table 1. Research Result

\begin{tabular}{ccccccc}
\hline & $\boldsymbol{N}$ & $\begin{array}{l}\text { Mean } \\
\text { PreTest }\end{array}$ & $\begin{array}{l}\text { Mean } \\
\text { PostTest }\end{array}$ & $\begin{array}{l}\text { Mean } \\
\text { sof } \\
\text { Diffe } \\
\text { rence }\end{array}$ & $\begin{array}{l}\text { T } \\
\text { score }\end{array}$ & $\begin{array}{l}\text { Sig } \\
(\boldsymbol{p})\end{array}$ \\
\hline $\begin{array}{c}\text { Definiti } \\
\text { on }\end{array}$ & 11 & 1.64 & 3.73 & -2.091 & -8.343 & 0.000 \\
Benefit & 11 & 2.73 & 4.18 & -1.455 & -5.882 & 0.000 \\
Stages & 11 & 2.09 & 3.73 & -1.636 & -4.500 & 0.001 \\
LP- I & 11 & 2.91 & 4.09 & -1.182 & -4.485 & 0.001 \\
LP - II & 11 & 2.73 & 3.55 & -.818 & -2.170 & 0.05 \\
LP - & 11 & 1.91 & 2.82 & -0.909 & -2.887 & 0.016 \\
III & & & & & & \\
\hline
\end{tabular}

Score on the table above, showing post test average increases from the pre test for each item. The biggest increase is the ability to explain what is the project approach (highest t score at 8.343) and the smallest increase is the ability to plan project approach stage 2 and 3 (lowest $t$ score of 2.170 and 2.887).

Overall, for sig $p$ score are $<0.05$ or $=0.05$, meaning that the difference or the increase of ability before and after the training is classified as significant difference.

\subsection{Discussion}

Looking at the research result above, training program seems necessary to be conducted for the kindergarten teachers before implementing the project approach. With better understanding and ability to design the project approach lesson plan, teachers are expected to be able to deliver project approach learning method that enhances competencies needed by children in facing the $21^{\text {st }}$ century.

Although there are some challenges and obstacles when implementing the research and training program such as 1) Number of participants that are limited, which the results of the research are unable to be generalise into the population 2) Timing of the training that is close to school year end or after school hour is felt by the participant to be reconsidered 3) Training material on planning and designing project approach stage 2 and 3 weren't executed optimally 4) Training method using lecture is felt by the participants not giving much insights 5) Video used was using a different language with the participants which result to a difficulty in understanding 6) Limitation on the facilitator of the training program that also role as the researcher felt to be ineffective, but the benefit resulted in the training program are seen with significant difference.

\section{CONCLUSIONS AND SUGGESTIONS}

\subsection{Conclusion}

Training program conducted for kindergarten teachers in DM and KP shows result of significant increase in the ability to explain on definition, benefit and stages of project approach. Although not as much increase as the ability to explain, the research also shows result of significant increase in the ability to plan and design a project approach lesson plan. The result shows a remarkable result for planning the first stage of the project approach lesson plan. However the second and third design result was not as optimal. 


\subsection{Suggestions}

Several suggestions from the researcher, for a better training program and further research as follow. First and most important is to increase the number of participants in order to achieve a better understanding of the result. Second would be to differentiate the person who is responsible for being the facilitator of the training and the person who is responsible of the research. As of regarding the implementation of the training program, several points to consider are to plan in advance timing of the training program, to enrich the program with concrete experience and active experiment for each session, and to enrich the program with more role play method.

For further training and research on the project approach, researcher should consider conducting the training and research for the whole three levels of program, not just concentrating on the knowledge and designing the project approach learning method, but also until mastering the implementation of the project approach. As for supporting children to increase their competencies facing the $21^{\text {st }}$ century, it would also be beneficial for parents to understand how to implement the project approach at home. Therefore, researcher may consider conducting such training and research not only for kindergarten teachers but also for parents.

\section{REFERENCES}

Biech, Elaine. 2005. Training for Dummies. Wiley Publishing, Inc. Indiana.

Chiem, David \& Caswell, Brian. 2009. The 3-Mind Revolution. A new world-view for all parents, educators, politicians and CEO's. Marshall Cavendish. Singapore.

Costa, Arthur L. \& Kallick, Bena. 2000. Activating \& Engaging Habits of Mind. Association for Supervision and Curriculum Development. Virginia.

Gonzalez-Mena, Janet. 2011. Foundations of Early Childhood Education. Teaching Children in a diverse Setting. $5^{\text {th }}$ Edition. McGraw Hill, New York.

Helm, Judy Harris \& Katz, Lilian G. 2001. Young Investigators, The Project Approach in the Early Years, Teachers College Press, New York

Katz, Lilian \& Chard, Sylvia. 2000. Engaging Children's Mind. The Project Approach. $2^{\text {nd }}$ edition. Ablex Publishing Corporation. Stamford, Connecticut.

Kritsonis, Alicia. 2005. Comparison of Change Theories. International Journal of Manangement, Business and Administration Vol. 8 Number 1. California State University.
Kunandar. 2007. Guru Profesional. Rajawali Pers. Jakarta Laird, Dugan. 2003. Approaches to Training and Development. $3^{\text {rd }}$ Edition. Perseus Publishing. US.

Lin, Yi Man Lin \& Moore, Lin \& Jang, Li-Fen Anne. 2012. Creating the Project Approach in Preschool. Journal for education of and advocacy for young children. Vol.31 No1. HAAEYC

Moyles, Janet; Georgeson, Jan \& Payler, Jane. 2011. Beginning Teaching, Beginning Learning. In Early Years and Primary Education. $4^{\text {th }}$ Edition. Mc Graw Hill. NY

Morrison, George. 2009. Early Childhood Education Today. $11^{\text {th }}$ Edition. Pearson.

NAEYC.1997.Developmentally Appropriate Practice in Early Childhood Programs.Wash.DC

Roopnarine, Jaipaul L. \& Johnson, James E. 2009. Pendidikan Anak Usia Dini. Dalam Berbagai Pendekatan. $5^{\text {th }}$ edition.. Terjemahan. Kencana, Jakarta. 